\title{
Characterization of soil-cement bricks with incorporation of used foundry sand
}

\section{(Caracterização de tijolos de solo-cimento com incorporação de areia descartada de fundição)}

\author{
R. F. Leonel', M. V. Folgueras ${ }^{2}$, L. V. O. Dalla Valentina ${ }^{2}$, S. R. Prim ${ }^{3}$, G. A. Prates ${ }^{4}$, J. C. Caraschi ${ }^{4}$ \\ ${ }^{1}$ Federal University of Paraná, R. XV de Novembro 1299, Curitiba, PR, Brazil \\ ${ }^{2}$ Department of Mechanical Engineering, University of the State of Santa Catarina, \\ R. Paulo Malschitzki 200, Joinville, SC, Brazil \\ ${ }^{3}$ Católica de Santa Catarina - Centro Universitário, R. Visc. de Taunay 427, Joinville, SC 89203-005 \\ ${ }^{4}$ São Paulo State University, R. Geraldo Alckmin 519, Itapeva, SP, Brazil \\ raquel.folmann@gmail.com,marilena.folgueras@udesc.br,luiz.valentina@udesc.br,sorprim@gmail.com, \\ glaucia@itapeva.unesp.br, "gprates@hotmail.com,caraschi@itapeva.unesp.br
}

\begin{abstract}
In order to contribute to the sustainability of the foundry and construction industrial sectors, this work investigated the possibility of employing used foundry sand (UFS) in soil-cement bricks. Modular bricks were prepared with percentages of $10 \mathrm{wt} \%$ cement, $0-25$ $\mathrm{wt} \%$ commercial sand, 0-65 wt $\%$ used foundry sand, 25-65 wt $\%$ clay, and 15-30 wt $\%$ gravel dust. A content of $10 \mathrm{wt} \%$ Portland cement was adopted to ensure economic feasibility, and gravel was used to improve mechanical strength. The modular bricks were tested to determine their technical properties. The interfaces between the constituent materials were observed by scanning electron microscopy. In durability tests, the bricks showed water absorption and weight loss in accordance with current technical standards. The addition of UFS together with gravel dust reduced water absorption and provided an acceptable level of mechanical resistance, in accordance with established soil-cement standards.
\end{abstract}

Keywords: soil-cement brick, used foundry sand, building ceramics, solid industrial waste.

\section{Resumo}

A fim de contribuir para a sustentabilidade de indústrias de fundição e de construção, este artigo estudou a possibilidade de areia descartada de fundição (ADF) ser incorporada em tijolos de solo-cimento. Tijolos modulares foram preparados com $10 \%$ de cimento, 0 a 25\% de areia comercial, 0 a 65\% de areia de fundição usada, 25 a 65\% de argila e 15 a $30 \%$ de pó de cascalho. Foi adoptado um teor de $10 \%$ de cimento Portland para assegurar a viabilidade econômica e cascalho foi usado para melhorar a resistência mecânica. Os tijolos modulares foram testados para determinar as suas propriedades tecnológicas. A interface entre os materiais constituintes foi observada por microscopia eletrônica de varredura. Nos testes de durabilidade, os tijolos apresentaram absorção de água e perda de massa de acordo com as normas técnicas existentes. A adição de areia descartada de fundição combinada com pó de brita reduziu absorção de água e manteve estável a resistência mecânica a niveis aceitáveis de padrões de solo-cimento.

Palavras-chave: solo-cimento, areia descartada de fundição, cerâmica, resíduos sólidos industriais.

\section{INTRODUCTION}

Sustainable development and the recycling and reuse of waste are widely researched topics. Current production models tend to be linear, with goods being conceived, designed, constructed and used, after which they accumulate in the environment. Sustainability requires closed or cyclic flow models for the production and consumption of materials [1]. Wastes generated by economic activities, such as industrial, agro-industrial and agricultural residues, together with municipal waste, are the major sources of materials that can be used in the housing and rural industry sectors, as well as for road paving, rural and urban infrastructure works, urban projects, embankments and containment facilities [2]. Research has shown that large quantities of waste could be successfully employed in the manufacture of building materials, improving their properties and durability [3].

Bricks have been used as a major construction and building material for a long time. They can be found as fired-clay or unfired-clay bricks. The former is most widely used but can be easily replaced by the latter in many applications, with a considerable reduction in energy usage [4]. The use of clay soil as a building material has followed human evolution. Adobe, which is a brick prepared with raw clay, followed by molding and sun-baking, has been used as a local and low cost material in several regions 
and periods. In the Neolithic period, it was made with high levels of kneading water, clay material, and straw. The main disadvantage of this type of material is its sensitivity to water, which can cause disintegration of the material and structural collapse. It is also affected by contraction and expansion, which can lead to cracking under adverse weather conditions, and has low resistance to abrasion [2]. These disadvantages can be controlled using stabilization additives such as asphalt, bitumen, lime, and Portland cement. Bitumen acts to waterproof soil grains, filling the capillary channels of pores. Lime and cement react with clay to form stable hydrated compounds [5].

The blending of cement and clay increases costs, but enables the preparation of bricks with uniform texture, regular dimensions, and flat surfaces. These bricks can be used as apparent bricks, requiring only an impermeable coating as a finish. They can be produced at work sites using simple and cheap equipment [6]. Several studies have investigated the addition of other waste materials to soil-cement. Where the aim is to reduce costs by partially replacing cement, these materials must have pozzolanic properties. Possibilities include mortar [7], concrete [8], pottery waste [9], kaolin processing waste [10], silica fume [11], ash from agroindustrial materials such as sugar cane bagasse [12] or rice husks [13], and blast furnace slag, among other options. Additional beneficial substances that can be used as fillers in the soil-cement mixture are dusts generated by the mining and processing of natural stones, where the extremely fine and inert particles help to fill empty spaces in the matrix. Additions of waste from other industrial activities can be trapped in the cement matrix, although there are limits to the replacement of soil that must be respected in order to avoid compromising the mechanical properties of the bricks [14].

One material that can be employed as filler is used foundry sand (UFS). It is estimated that 3 million tons of UFS are produced each year in Brazil [15]. The volume generated and the environmental impact of disposal justifies studies aimed at the employment of this sand as a raw material for the production of construction and paving materials $[16,17]$. The monitoring and control of tailings to avoid possible contamination are essential for the reuse of sand. The worst contaminants are associated with organic binders that are not degraded during leakage and can be a source of hazardous compounds [16]. For this reason, possible applications of used foundry sand focus on green sand tailings, in which binders are inorganic and do not constitute a health hazard. This work examined the feasibility of recycling used foundry sand for the production of soil-cement bricks for masonry sealing. This approach is economically justified by the low cost of the materials and low energy consumption achieved by prioritizing the use of local materials. It is environmentally justified by the use of recycled materials to replace natural resources, reducing both extraction and the demand for industrial landfills. It is also socially justified by its simple technology and applicability in both urban and rural human settlements, contributing to greater sustainability of building materials.

\section{EXPERIMENTAL}

The materials used in this research were kaolinite clay, commercial sand, used foundry sand, crushed stone powder, and Portland cement. The basic characterization of these materials was carried out in accordance with Brazilian and other internationally accepted engineering standards.
The used foundry sand was collected from a foundry plant located in south Brazil, in accordance with the sampling procedures for solid waste described in the NBR 10007 standard [18]. The sand was obtained from the casting process of automotive blocks.

Mineralogical analysis of the collected material was performed by X-ray diffraction, using a conventional diffractometer (XRD-6000, Shimadzu). The chemical composition of the foundry sand was determined by X-ray fluorescence (XRF). The pollution potentials of the used foundry sand and the other materials used in this research were evaluated by leaching and solution tests in aqueous media, performed following the Brazilian NBR 10005 [19] and NBR 10006 [20] standards. The concentrations of elements present in the leaching and solution extracts were then determined and compared with the maximum contents of elements allowed according to the Brazilian NBR 10004 standard [21]. Characterization of the clay included determination of particle size by sieving, sedimentation, and analysis of specific mass and liquid limit. These assays were carried out in accordance with the NBR 7181 [22], NBR 6508 [23], and NBR 6459 [24] Brazilian standards, respectively. The waste foundry sand and crushed stone powder were also characterized by sieving.

An isothermal calorimetric test was carried out to evaluate the influence of used foundry sand and clay on the cement hydration process. This test was carried out using cement alone or mixtures of cement with small additions of clay and UFS. The raw materials were weighed out (Table I) and stirred for 2 min before being transferred to the sample holder of a TAM Air calorimeter. In this test, the energy released during cement hydration was quantified by monitoring the heat flow in a controlled environment. All the tests employed the addition of a $25 \mathrm{wt} \%$ of water. A small quantity of cement was used, with the aim of minimizing costs, and the percentage combinations of sand and soil employed ensured the workability characteristics recommended for soil-cement bricks [25].

The raw materials were mixed and homogenized for the production of bricks. The first tests employed only soil, used foundry sand, sand and cement. Subsequent experiments included crushed stone powder (Table II). The materials were previously dried and the soil was sieved through a $4.8 \mathrm{~mm}$ sieve. The bricks were manufactured using a commercial press that produced two bricks at a time, with uniaxial

Table I - Mixture proportions (wt $\%$ ) used in the calorimetric tests.

[Tabela I - Proporções de misturas usadas no teste calorimétrico (\% em massa).]

\begin{tabular}{ccc}
\hline UFS & Clay & Cement \\
\hline 0 & 0 & 100 \\
0 & 10 & 90 \\
0 & 30 & 70 \\
10 & 30 & 60 \\
\hline
\end{tabular}


Table II - Mixture proportions (wt $\%$ ) used for the bricks. [Tabela II - Dosagens das misturas usadas para tijolos $(\%$ em massa).]

\begin{tabular}{ccccc}
\hline Sand & UFS & Clay & Stone & Cement \\
\hline 25 & 0 & 65 & 0 & 10 \\
0 & 25 & 65 & 0 & 10 \\
0 & 45 & 45 & 0 & 10 \\
0 & 65 & 25 & 0 & 10 \\
0 & 30 & 30 & 30 & 10 \\
30 & 0 & 30 & 30 & 10 \\
0 & 35 & 35 & 20 & 10 \\
0 & 45 & 30 & 15 & 10 \\
45 & 0 & 30 & 15 & 10 \\
\hline
\end{tabular}

pressing at 100 bar $(10 \mathrm{MPa})$. The molds were adapted to produce two-holed $30 \mathrm{~cm} \times 15 \mathrm{~cm} \times 7.5 \mathrm{~cm}$ modular soilcement bricks. After being pressed, the bricks were placed in wooden supports and wrapped with plastic to conserve moisture during the 7 days curing period.

The technical properties of the bricks were determined in accordance with standardized procedures, considering tensile strength (NBR 10836 [26]), water absorption (NBR 8492 [27]), and durability (NBR 13554 [28]). The compression test involved applying compressive axial loads to six samples of bricks of each composition. Prior to the test, the brick sides were flattened with cement-water paste and then immersed in water for $24 \mathrm{~h}$. The durability test involved six cycles of wetting, drying and brushing with a steel bristle brush. Each cycle consisted of $5 \mathrm{~h}$ of immersion in water and $42 \mathrm{~h}$ of drying in an oven at $71{ }^{\circ} \mathrm{C}$, after which brushing was performed. The durability was then calculated as the weight loss obtained based on the initial dry weight and the final dry weight after reaching a constant mass in an oven at $105^{\circ} \mathrm{C}$. Small fragments of the test samples were used in the microstructural analysis. After plating with gold, the sample surfaces were examined using a Zeiss DSM 940 scanning electron microscope (SEM) operated at $15 \mathrm{kV}$ and $80 \mu \mathrm{A}$ current.

\section{RESULTS AND DISCUSSION}

The X-ray diffraction pattern of the clay used as the soil component in this work confirmed the presence of kaolinite and bentonite as the clay minerals, with quartz as a secondary crystalline phase. The specific density of the clay was $2.54 \mathrm{~g} / \mathrm{cm}^{3}$ and the plasticity index was $23.4 \%$, as determined by the Atterberg method, which defines the plastic limit as $30.46 \%$ and the liquid limit as $53.86 \%$. These values were indicative of low quartz content of the clay, which could therefore be defined as plastic clay. The addition of $30 \mathrm{wt} \%$ of sand to the clay decreased the liquid limit to $37.21 \%$.

The X-ray diffraction pattern of the used sand is shown in Fig. 1. The crystalline phases found were quartz $\left(\mathrm{SiO}_{2}\right)$ and montmorillonite, with predominance of quartz. The chemical composition and mass loss of the used sand sample are provided in Table III. According to these data, the used sand contained a large quantity of silica $(76.91 \mathrm{wt} \%)$ and lesser amounts of alumina $\left(\mathrm{Al}_{2} \mathrm{O}_{3}\right)$, calcium oxide $(\mathrm{CaO})$, iron oxide $\left(\mathrm{Fe}_{2} \mathrm{O}_{3}\right)$, and potassium oxide $\left(\mathrm{K}_{2} \mathrm{O}\right)$. These results were consistent with the X-ray diffraction data (Fig. 1). The weight loss of about $2.93 \mathrm{wt} \%$ could be attributed to the presence of carbon in the UFS sample. The presence of carbon can adversely affect the manufacture of bricks, but this effect is greatest for fired bricks.

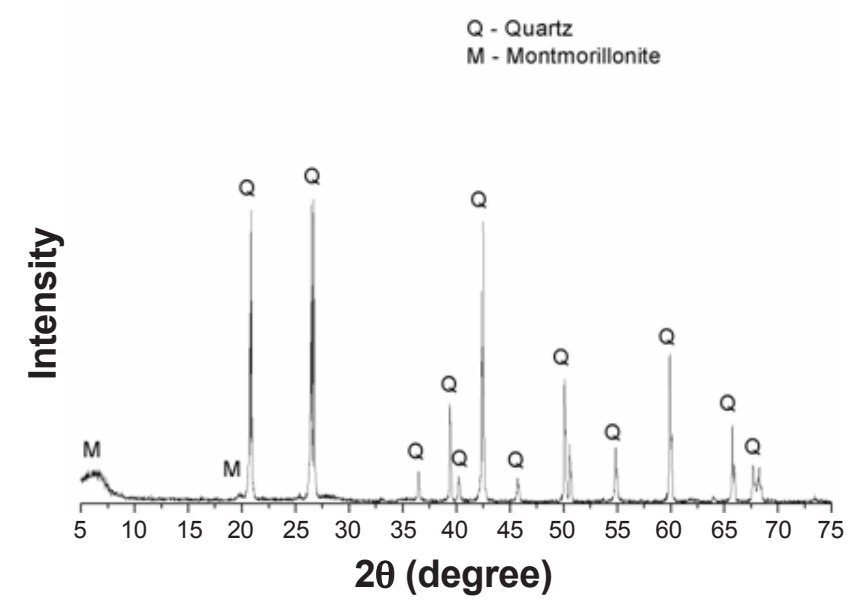

Figure 1: X-ray diffraction pattern of the used foundry sand.

[Figura 1: Difratograma de raios $X$ da areia descartada de fundição.]

The ecotoxicities of the UFS, cement, and clay were evaluated using leaching and solution tests, as shown in Tables IV and V. The leachate analysis (Table IV) showed that the values of the parameters evaluated did not exceed the limits established in the NBR 10004 standard, attachment $\mathrm{G}$ [21]. The materials used could therefore be classified as non-hazardous and without any health risks. In the solution tests (Table V), the UFS sample also presented values below the maximum limits established in the NBR 10004 standard [21]. The solubilized content analysis resulted

Table III - Chemical composition by XRF analysis (wt\%) of the used foundry sand.

[Tabela III - Composição química da areia descartada de fundição determinada por FRX (\% em massa).]

\begin{tabular}{lccccccccc}
\hline $\mathrm{SiO}_{2}$ & $\mathrm{Al}_{2} \mathrm{O}_{3}$ & $\mathrm{Fe}_{2} \mathrm{O}_{3}$ & $\mathrm{TiO}_{2}$ & $\mathrm{CaO}$ & $\mathrm{MgO}$ & $\mathrm{K}_{2} \mathrm{O}$ & $\mathrm{MnO}$ & $\mathrm{Na}_{2} \mathrm{O}$ & LOI* $^{*}$ \\
\hline 76.91 & 9.49 & 3.43 & 0.80 & 0.96 & 0.97 & 1.06 & 0.02 & 0.72 & 2.93 \\
\hline *- loss of ignition at $1000^{\circ} \mathrm{C}$. & & & & & & &
\end{tabular}


in classification of the UFS as non-inert class II-A waste, because the contents of aluminum, iron and phenol exceeded the specified limits. Phenol is not a component of the green

Table IV - Results of leaching tests of the materials used (mg.L-1-1).

[Tabela IV - Resultados do teste de lixiviação dos materiais usados $\left.\left(m g \cdot L^{-1}\right) \cdot\right]$

\begin{tabular}{ccccc}
\hline Specie & UFS & Cement & Clay & $\begin{array}{c}\text { NBR } \\
10005 \\
\text { limit }\end{array}$ \\
\hline $\mathrm{Ag}$ & $<0.02$ & $<\mathrm{LQ}$ & $<\mathrm{LQ}$ & 5.0 \\
$\mathrm{As}$ & $<1.0 \times 10^{-4}$ & $<\mathrm{LQ}$ & $<\mathrm{LQ}$ & 1.0 \\
$\mathrm{Ba}$ & $<0.02$ & 0.23 & 1.14 & 70.0 \\
$\mathrm{Cd}$ & $<0.001$ & $<\mathrm{LQ}$ & $<\mathrm{LQ}$ & 0.5 \\
$\mathrm{Cr}$ (total) & $<0.03$ & 0.15 & 0.008 & 5.0 \\
$\mathrm{Hg}$ & $<1.0 \times 10^{-4}$ & $<\mathrm{LQ}$ & $<\mathrm{LQ}$ & 0.1 \\
$\mathrm{Se}$ & $<1.0 \times 10^{-4}$ & $<\mathrm{LQ}$ & $<\mathrm{LQ}$ & 1.0 \\
Fluoride & $<1.00$ & 0.49 & 0.11 & 150.0 \\
\hline
\end{tabular}

LQ: quantification limit.

Table V - Results of solution tests of the materials used (mg. $\mathrm{L}^{-1}$ ).

[Tabela V - Resultados dos testes de solubilização dos materiais usados $\left.\left(m g . L^{-1}\right).\right]$

\begin{tabular}{ccccc}
\hline Specie & UFS & Cement & Clay & $\begin{array}{c}\text { NBR } \\
10005 \\
\text { limit }\end{array}$ \\
\hline $\mathrm{Ag}$ & $<0.02$ & $<\mathrm{LQ}$ & $<\mathrm{LQ}$ & 0.05 \\
$\mathrm{Al}$ & 44.26 & 0.09 & 1.86 & 0.2 \\
$\mathrm{As}$ & $3.99 \times 10^{-4}$ & 0.004 & $<\mathrm{LQ}$ & 0.01 \\
$\mathrm{Ba}$ & $<0.2$ & 0.32 & 0.33 & 0.7 \\
$\mathrm{Cd}$ & 0.001 & $<\mathrm{LQ}$ & $<\mathrm{LQ}$ & 0.005 \\
$\mathrm{Cu}$ & $<0.005$ & 0.005 & 0.004 & 2.0 \\
$\mathrm{Cr}$ (total) & $<0.030$ & 0.38 & 0.007 & 0.05 \\
$\mathrm{Fe}$ (total) & 25.988 & $<\mathrm{LQ}$ & 0.38 & 0.3 \\
$\mathrm{Hg}$ & $<1.0 \mathrm{x} 10^{-4}$ & $<\mathrm{LQ}$ & $<\mathrm{LQ}$ & 0.001 \\
$\mathrm{Mn}$ & $<0.005$ & 0.004 & 0.02 & 0.1 \\
$\mathrm{Na}$ & 127.53 & 269 & 3.96 & 200 \\
$\mathrm{~Pb}$ & $<0.01$ & 0.002 & $<\mathrm{LQ}$ & 0.01 \\
$\mathrm{Se}$ & $<1.0 \mathrm{x} 10^{-4}$ & 0.002 & $<\mathrm{LQ}$ & 0.01 \\
$\mathrm{Zn}$ & 0.019 & 0.040 & 0.11 & 5.0 \\
Cyanide & $<0.005$ & 0.014 & 0.0063 & 0.07 \\
Chloride & 49.67 & 21.8 & 1.80 & 250 \\
Phenol & 0.125 & 0.014 & 0.006 & 0.01 \\
Fluoride & $<1.000$ & 0.39 & 0.074 & 1.5 \\
Nitrate & 8.00 & 2.03 & 0.56 & 10 \\
Sulfate & 50.48 & 13.44 & 8.51 & 250 \\
\hline L $:$ quantification limit. & & &
\end{tabular}

sand used for molding, but is present in core sand, which may have been mixed during the process of de-molding the castings. According to the solution analyses, the cement and soil could be classified as non-inert waste. In the case of the cement, the parameters that exceeded the specified limits were chromium, phenol, sodium and sulfate. For the soil, only aluminum and iron exceeded the limits, since their natural components and elements are abundant in the Earth's crust.

The particle size distributions of the UFS, clay, and crushed stone samples are shown in Fig. 2. The UFS showed a particle size intermediate between clay and fine commercial aggregate, with $10 \mathrm{wt} \%$ below $0.1 \mathrm{~mm}, 10 \mathrm{wt} \%$ above $0.5 \mathrm{~mm}$, and an average diameter of $0.25 \mathrm{~mm}$. This reflected a material with a narrow particle size distribution, concentrated in the sand fraction.

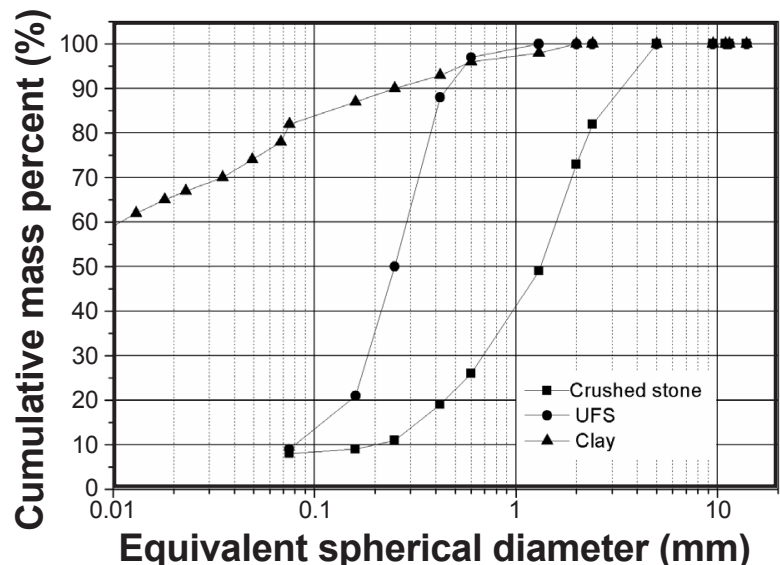

Figure 2: Particle size distributions of the used foundry sand, clay and crushed stone.

[Figura 2: Curvas granulométricas para os materiais solo, areia descartada de fundição e pó de brita.]

Calorimetric analysis of the UFS combined with cement, soil and water was performed in order to evaluate the influence of the UFS in the cement hydration process. Isothermal (heat conduction) calorimetry was used to construct curves of heat release versus hydration time (Fig. 3). The cement hydration curve showed an initial heat peak immediately after the addition of water, followed by a period of low energy. The period of maximum heat release occurred $20 \mathrm{~h}$ after the start of the reaction. For the soilcement, the initial heat of dissolution was also high and the induction period was greatly reduced. Considering the formulations with 10 and $30 \mathrm{wt} \%$ of cement plus soil, the highest intensity peak was obtained for $30 \mathrm{wt} \%$ of cement, since this component was most reactive and responsible for energy release. The presence of soil accelerated cement hydration, associated with higher initial heat flux. The addition of UFS interfered with the reaction between soil and cement, reducing the energy released during hydration, comparing equivalent contents of cement $(30 \mathrm{wt} \%)$ with and without UFS.

Molded bricks were prepared using $10 \mathrm{wt} \%$ of cement, 


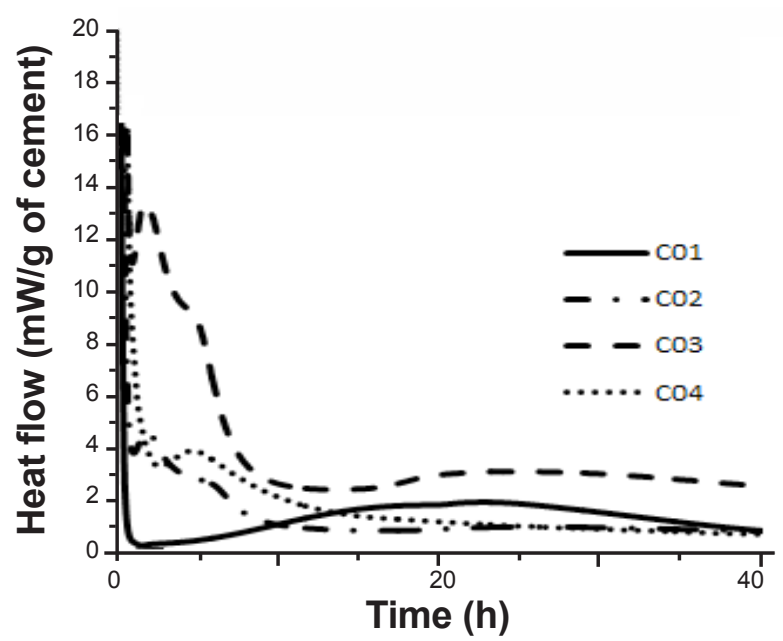

Figure 3: Heat conduction calorimetry analysis of the combined materials: C01 (cement + water), $\mathrm{C} 02$ (cement $+30 \mathrm{wt} \%$ of soil $+10 \mathrm{wt} \%$ of used sand), $\mathrm{C} 03$ (cement $+30 \mathrm{wt} \%$ of soil), and $\mathrm{C} 04$ (cement $+10 \mathrm{wt} \%$ of soil).

[Figura 3: Calorimetria dos materiais combinados: C01 (cimento + água); C02 (cimento $+30 \%$ de solo $+10 \%$ de areia usada); C03 (cimento $+30 \%$ de solo); C04 (cimento $+10 \%$ de solo), $\%$ em massa.]

$65 \mathrm{wt} \%$ of clay, and $25 \mathrm{wt} \%$ of sand. Bricks obtained using commercial sand presented a compressive strength of 1.49 $\mathrm{MPa}$, while a value of $0.92 \mathrm{MPa}$ was obtained with foundry sand after seven days curing. Extending the cure time to 28 days increased the compressive strength of the bricks prepared with UFS to $1.33 \mathrm{MPa}$, while no difference was observed for the bricks prepared with commercial sand. This showed that the used foundry sand affected the process of cement hydration. The mechanical strength of the clay brick pieces did not change significantly with increased content of UFS (Fig. 4). The greater sand content resulted in reduced water absorption, suggesting a reduction in the volume of open pores. This behavior can be associated with higher

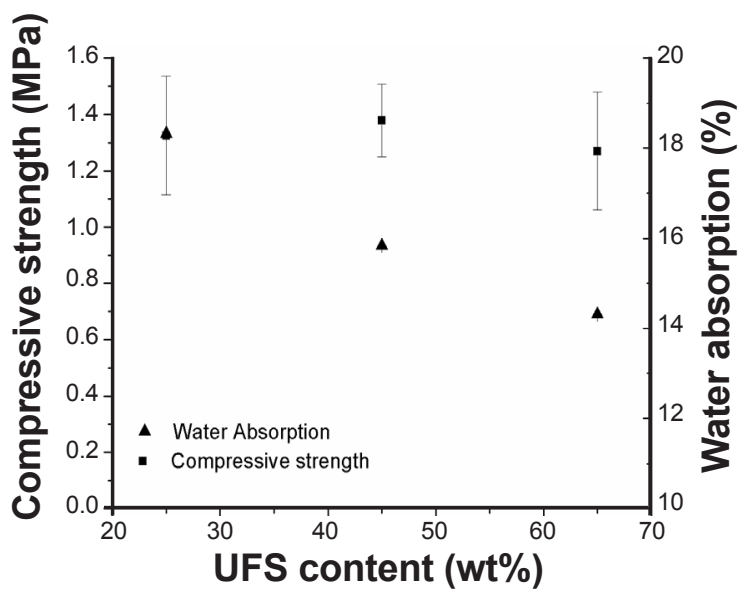

Figure 4: Clay brick compressive strength and water absorption, according to used foundry sand (UFS) content, after 28 days of curing.

[Figura 4: Resistência à compressão e absorção de água para tijolos de solo-cimento em função do teor de areia usada de fundição (UFS) após 28 dias de cura.] densification in the production of bricks.

The standard for massive bricks establishes a minimum of $2 \mathrm{MPa}$ for compressive strength. Reduced mechanical properties are expected for brick geometries with holes, in light of which it cannot be said that the addition of foundry sand makes the production of soil-cement bricks unviable. With the aim of enhancing the mechanical performance of the bricks, addition was made of clay at $30-35 \mathrm{wt} \%$ and gravel dust at $15-30 \mathrm{wt} \%$. The cement content was maintained at $10 \mathrm{wt} \%$. Gravel dust was added to the mixture because its larger grain size compensated the high percentage of fine grains of clay, silt and fine sand. The content of soil was increased to improve brick cohesion, de-molding, and early strength. Reference samples produced without UFS were employed in order to evaluate its effect in the mixtures. The results obtained after seven days curing (Fig. 5) showed that replacing the commercial sand with UFS decreased the compressive strength. It was also found that an increased clay content and the addition of gravel dust effectively increased brick resistance. The use of $15 \mathrm{wt} \%$ of gravel dust ensured good brick performance.



Figure 5: Compressive strength of clay bricks prepared with sand, clay and gravel dust, employing different weight ratios of used foundry sand and gravel dust.

[Figura 5: Resistência à compressão para tijolos de solo-cimento preparados com areia, argila e pó de brita considerando diferentes proporções em massa de areia usada de fundição e poeira de cascalho.]

The strength of the bricks was influenced by their composition, particle size distribution, and activity of each component in the mixture. Soil ensured cohesion between the components and provided initial strength; UFS and gravel dust provided filling and the formation of a compact structure with good particle size distribution; cement ensured long-term physical and chemical strength, due to its hydration products. Fig. 6 shows SEM images of typical brick microstructures at surface fractures after compressive strength testing. Poorly interconnected aggregates were present in the porous microstructure (Fig. 6a), together with a fibrous network linking the aggregates (Fig. 6b), which was 

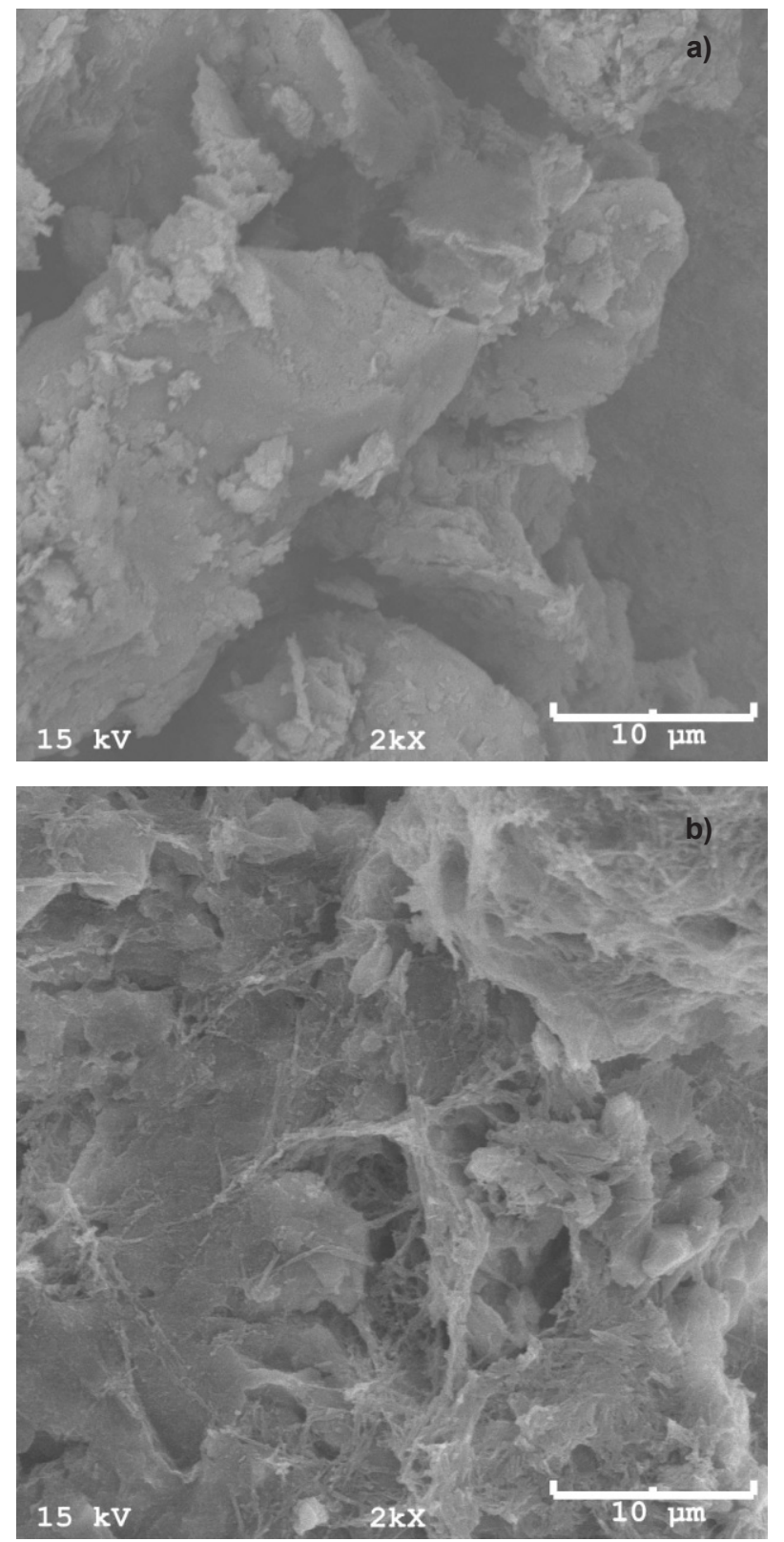

Figure 6: SEM micrographs of surface fractures on the clay bricks: (a) poorly interconnected aggregates in the porous microstructure; (b) formation of a fibrous network linking the aggregates.

[Figura 6: Micrografias obtidas por microcoscopia eletrônica de varredura da superficie de fratura dos tijolos de solo-cimento: (a) agregados fracamente interligados a uma microestrutura porosa; e (b) formação de uma rede fibrosa que liga os agregados.]

formed during cement hydration and was partly responsible for the mechanical behavior.

In the durability test, weight loss was determined after six wetting, drying and brushing cycles. The results showed that durability decreased with increased addition of UFS. The lowest weight loss $(2.8 \%)$ was obtained for the mixture without used sand, while a value of $7.5 \%$ was obtained when $50 \mathrm{wt} \%$ of UFS were used. The presence of larger quantities of used foundry sand resulted in brick rupture. The durability test resulted in worn brick sides that had small surface cracks and imperfections, with the bricks produced without addition of UFS showing better quality surfaces.

\section{CONCLUSIONS}

The results indicated that recycled sand from the foundry industry has potential for use in unfired brick production. Used foundry sand (UFS) is rich in crystalline silica and can replace commercial sand. This material also contains montmorillonite, which interacts with clay to improve brick cohesion, de-molding and strength. The presence of carbon might adversely affect brick properties, although it is believed that these effects should be lower than for fired bricks. Leaching and solution tests indicated that the used foundry sand could be classified as a Class II-A waste material (non-inert), according to the Brazilian standards. The replacement of commercial sand by the foundry sand resulted in reduced brick mechanical strength, but this reduction did not preclude the use of UFS to obtain bricks that provided adequate performance. Increase in the UFS content did not lead to any significant reduction in mechanical strength. In addition, the presence of UFS resulted in decreased water absorption, which can improve densification. Adjustment of brick composition using greater amounts of soil and the inclusion of gravel dust resulted in a significant increase in mechanical resistance, showing that it is possible to obtain bricks that meet market needs by using the correct proportions of the materials employed. The use of waste foundry sand in unfired bricks is feasible and offers environmental advantages. The process reduces raw material consumption and avoids the need for kiln firing.

\section{ACKNOWLEDGEMENTS}

The authors wish to thank CAPES for financial support and Tupy S/A for providing the samples.

\section{REFERENCES}

[1] J.L. Calmon, "Resíduos industriais e agrícolas", In: G.C. Isaia (Ed.), Materiais de construção civil e princípios de ciência e engenharia de materiais, IBRACON, S. Paulo (2007).

[2] W.J. Freire, Tecnologias e materiais alternativos de construção, Ed. da UNICAMP, Campinas (2003).

[3] J. Malaiškienė, M. Vaičienė, R. Žurauskienè, Constr. Build. Mater. 25 (2011) 3869-3877.

[4] L. Zhang, Constr. Build. Mater. 47 (2013) 643-655.

[5] K. Ghavami, N.P. Barbosa, "Terra crua para edificações", In: G.C. Isaia (Ed.). Materiais de construção civil e princípios de ciências e engenharia de materiais, IBRACON, S. Paulo (2007).

[6] L.A. Pecoriello, J.M.C. Barros, Techne 87 (2004) 58-61. [7] S. Vimala, K. Kumarasamy, Int. J. Emerg. Technol. Adv. Eng. 4.4 (2014) 720-724. 
[8] M.I.B. Souza, A.A.S. Segantini, J.A. Pereira. Rev. Bras. Eng. Agríc. Ambient. 12, 2 (2008) 205-212.

[9] R. Dallacort, A.N.P. Lima Jr, Rev. Bras. Eng. Agríc. Ambient. 6, 3 (2002) 511-518.

[10] R.R. Menezes, G.A. Neves, J. Souza, W.A. Melo, H.S. Ferreira, H.C. Ferreira, Rev. Bras. Eng. Agríc. Ambient. 13, 6 (2009) 795-801.

[11] M.S. Barata, R.S. Angélica, Cerâmica 58, 345 (2012) 36-42.

[12] M.C. Mesa Valenciano, W.J. Freire, Eng. Agríc. 24, 3 (2004) 484-492.

[13] A.P.M. da Silva, W.J. Freire, Teoria Prática Eng. Civil 11 (2008) 23-30.

[14] F.B. Siqueira, J.N.F. Holanda, Cerâmica 61, 360 (2015) 414-419.

[15] ABIFA, Manual de regeneração e reuso de areias de fundição, São Paulo (2009).

[16] R. Siddique, Y. Aggarwal, P. Aggarwal, E.H. Kadri, R. Bennacer, Constr. Build. Mater. 25 (2011)1916-1925.

[17] R. Siddique, G. Singh, Res. Conserv. Recyc. 55 (2011) 885-892.

[18] Assoc. Bras. Nor. Tecn., NBR 10007, "Sampling of solid waste" (2004).

[19] Assoc. Bras. Nor. Tecn., NBR 10005, "Leaching test procedure" (2004).

[20] Assoc. Bras. Nor. Tecn., NBR 10006, "Solution test procedure" (2004).

[21] Assoc. Bras. Nor. Tecn., NBR 10004, "Solid waste: classification" (2004).

[22] Assoc. Bras. Nor. Tecn., NBR 7181, “Soil: granulometric analysis" (1984).

[23] Assoc. Bras. Nor. Tecn., NBR 6508, "Grains of soil passing through the sieve of $4.8 \mathrm{~mm}$ - determination of bulk density" (1984).

[24] Assoc. Bras. Nor. Tecn., NBR 6459, "Determination of liquid limit" (1984).

[25] R. Folmann, "Estudo da aplicação de areia descartada de fundição em tijolos de solo-cimento", Master's thesis, State Un. Santa Catarina, Joinville (2012).

[26] Assoc. Bras. Nor. Tecn., NBR 10836, "Hollow soilcement block without structural function - determination of compressive strength and water absorption" (1994).

[27] Assoc. Bras. Nor. Tecn., NBR 8492, "Massive soilcement brick - determination of compressive strength and water absorption" (1984).

[28] Assoc. Bras. Nor. Tecn., NBR 13554, "Soil cement durability test by wetting and drying" (1996).

(Rec. 03/08/2016, Rev. 21/09/2016, 14/12/2016, Ac. 14/12/2016) 